\title{
Estimating Nitrogen Availability of Heat-Dried Biosolids
}

\author{
Craig G. Cogger, Andy I. Bary, and Elizabeth A. Myhre \\ Washington State University Puyallup Research and Extension Center, 2606 W. Pioneer Ave Puyallup, WA 98371, USA \\ Correspondence should be addressed to Craig G. Cogger, cogger@wsu.edu
}

Received 14 December 2010; Revised 16 February 2011; Accepted 26 February 2011

Academic Editor: Robert Edwin White

Copyright ( $) 2011$ Craig G. Cogger et al. This is an open access article distributed under the Creative Commons Attribution License, which permits unrestricted use, distribution, and reproduction in any medium, provided the original work is properly cited.

\begin{abstract}
As heat-dried biosolids become more widely produced and marketed, it is important to improve estimates of $\mathrm{N}$ availability from these materials. Objectives were to compare plant-available $\mathrm{N}$ among three different heat-dried biosolids and determine if current guidelines were adequate for estimating application rates. Heat-dried biosolids were surface applied to tall fescue (Festuca arundinacea Schreb.) in Washington State, USA, and forage yield and N uptake measured for two growing seasons following application. Three rates of urea and a zero- $\mathrm{N}$ control were used to calculate $\mathrm{N}$ fertilizer efficiency regressions. Application year plant-available $\mathrm{N}$ (estimated as urea $\mathrm{N}$ equivalent) for two biosolids exceeded $60 \%$ of total $\mathrm{N}$ applied, while urea $\mathrm{N}$ equivalent for the third biosolids was $45 \%$. Residual (second-year) urea N equivalent ranged from 5 to $10 \%$. Guidelines for the Pacific Northwest USA recommend mineralization estimates of 35 to $40 \%$ for heat-dried biosolids, but this research shows that some heat-dried materials fall well above that range.
\end{abstract}

\section{Introduction}

Heat-dried biosolids are convenient to use in a variety of applications. The Class A heat-dried product is suitable as a fertilizer on lawns and gardens as well as for agricultural crops. Heat-dried biosolids are easy to transport and handle and are applied like inorganic fertilizers, except at higher rates.

Because a large proportion of the nitrogen $(\mathrm{N})$ in biosolids is in organic form, biosolids act as a slow-release $\mathrm{N}$ source, dependent on biological transformation of the organic $\mathrm{N}$ into available forms. Accurate estimates of the mineralization rate of biosolids $\mathrm{N}$ are critical to developing application rate recommendations that meet plant needs without compromising environmental quality. Smith and Durham [1] used laboratory incubation to compare five different biosolids sources with and without heat drying, and found that the mineralization rates of the heat-dried biosolids were more than double the undried (dewatered only) materials. This rapid mineralization more than compensated for the lower initial ammonium $\mathrm{N}$ in the heatdried biosolids. Rigby et al. [2] observed similar results in a field incubation, estimating mineralizable $\mathrm{N}$ from heatdried biosolids at twice that for dewatered biosolids. Mat- suoka et al. [3] and Moritsuka et al. [4] produced heat-dried biosolids in an experimental scale vessel reaching final temperatures of 120 and $180^{\circ} \mathrm{C}$. They found increased available $\mathrm{N}$ in the $120^{\circ} \mathrm{C}$ heat-dried biosolids compared with undried biosolids in laboratory incubation and pot studies. Heat drying to a final temperature of $180^{\circ} \mathrm{C}$ reduced available $\mathrm{N}$.

Few quantitative field estimates of $\mathrm{N}$ availability from heat-dried biosolids have been published. Cogger et al. [5] estimated $32 \%$ and $44 \%$ first-year plant available N\% (PAN) for two heat-dried biosolids compared with ammonium nitrate applied to tall fescue (Festuca arundinacea Schreb.) in western Washington State, USA. Plant-available N\% from dewatered and air-dried biosolids ranged from 29 to $43 \%$ in the same study. Gavalda et al. [6] reported $45 \%$ PAN (estimated as urea $\mathrm{N}$ equivalent) in a field study on maize (Zea mays L.) in southwestern France. In a longterm comparison of one heat-dried and one dewatered Class A biosolids, Cogger et al. [7] found the heat-dried and dewatered biosolids had similar long-term $\mathrm{N}$ availability following repeated applications.

As heat-dried biosolids become more widely produced and marketed, it is important to improve our understanding of $\mathrm{N}$ availability from these materials. In this study we compare two heat-dried biosolids from new facilities in western 
TABLE 1: Biosolids nitrogen, $\mathrm{pH}$, and solids.

\begin{tabular}{|c|c|c|c|c|c|}
\hline Biosolids dry product & Total $\mathrm{N}\left(\mathrm{g} \mathrm{kg}^{-1}\right)$ & Ammonium-N $\left(\mathrm{g} \mathrm{kg}^{-1}\right)$ & C: $N$ & Solids $\left(\mathrm{g} \mathrm{kg}^{-1}\right)$ & $\mathrm{pH}$ \\
\hline Soundgro & 57 & 3.5 & 5.4 & 950 & 7.0 \\
\hline Milorganite & 63 & 2.5 & 5.4 & 960 & 6.2 \\
\hline Sumner & 51 & 2.5 & 6.1 & 890 & 6.7 \\
\hline
\end{tabular}

TABLE 2: Particle size distribution of biosolids dry products.

\begin{tabular}{|c|c|c|c|c|c|}
\hline & $>4.76 \mathrm{~mm}$ & 2 to $4.76 \mathrm{~mm}$ & $\begin{array}{c}1 \text { to } 2 \mathrm{~mm} \\
\text { Percent }\end{array}$ & 0.425 to $1 \mathrm{~mm}$ & $<0.425 \mathrm{~mm}$ \\
\hline Soundgro & 0 & 53 & 33 & 13 & $<1$ \\
\hline Sumner & 7 & 40 & 37 & 14 & 2 \\
\hline Milorganite & 0 & 13 & 72 & 14 & 0 \\
\hline
\end{tabular}

Washington with Milorganite, a well-established heat-dried product from Milwaukee, WI, USA. Our objectives were to compare amount and timing of $\mathrm{N}$ availability among these materials and determine if current guidelines were adequate for estimating application rates.

\section{Methods}

2.1. Biosolids. Heat-dried biosolids sources included Milorganite, Soundgro from Pierce County, WA, and Sumner biosolids from the City of Sumner, Washington. Milorganite is marketed nationally as a lawn fertilizer. Milorganite is dried in a rotary kiln drier at $450-650^{\circ} \mathrm{C}$ for 40 minutes. It was at the high end of the range of first-year PAN (44\%) in the Cogger et al. [5] study cited above. Pierce County began producing Soundgro in 2006. Soundgro is dried in a rotating drum Andritz dryer with an inlet temperature of 455 to $480^{\circ} \mathrm{C}$ and outlet temperature of $100^{\circ} \mathrm{C}$ (Andritz Group; Gras, Austria). The facility at Sumner, Washington also opened in 2006. It produces heat-dried biosolids on a smaller scale using a Fenton dryer (Fenton Environmental Technologies, Inc; Brownwood, Tex, USA). The Fenton process at the Sumner plant uses thermal oil indirect drying at $150^{\circ} \mathrm{C}$ for four hours. Annual production is approximately 39,000 $\mathrm{Mg} \mathrm{yr}^{-1}$ for Milorganite, $2200 \mathrm{Mg} \mathrm{yr}^{-1}$ for Soundgro, and $270 \mathrm{Mg} \mathrm{yr}^{-1}$ for Sumner biosolids, on a dry weight basis. Biosolids properties are shown in Tables 1 and 2.

2.2. Field Experiment. The experiment was done at the Washington State University Puyallup Research and Extension Center, located in western Washington State, $60 \mathrm{~km}$ south of Seattle. The soil is a Puyallup fine sandy loam (coarse loamy over sandy, mixed, isotic, mesic Vitrandic Haploxerolls) as classified by the US Department of Agriculture Soil Taxonomy [8]. It is a deep, well-drained soil formed in recent alluvium, and contains $470 \mathrm{~g} \mathrm{~kg}^{-1}$ sand, $460 \mathrm{~g} \mathrm{~kg}^{-1}$ silt, $70 \mathrm{~g} \mathrm{~kg}^{-1}$ clay, and $16 \mathrm{~g} \mathrm{~kg}^{-1}$ organic C. The climate is typical of the maritime Pacific Northwest with cool, wet winters, and mild, dry summers. Mean January temperature is $4^{\circ} \mathrm{C}$, mean July temperature is $18^{\circ} \mathrm{C}$, and mean annual precipitation is
$1020 \mathrm{~mm}$. A pronounced summer dry season necessitates supplemental irrigation for crops and pastures most years.

A stand of tall fescue "A.U. Triumph" was established in 2005 and maintained with irrigation, inorganic fertilizers, mowing, and harvesting until the start of the experiment. The experiment consisted of two trials on adjacent areas of the tall fescue stand. Trial A began in 2007 and Trial B in 2008. Each trial was a randomized complete block design with 10 treatments and four replications. Individual plots measured $1.6 \times 4.6 \mathrm{~m}$. Treatments included three heat-dried biosolids (Pierce County Soundgro, Sumner, and Milorganite) each applied at a single rate, but at two timings (all in April, or split between April and June) for a total of six biosolids treatments (Table 3 ). The remaining four treatments were three inorganic $\mathrm{N}$ (urea) rates and a zero$\mathrm{N}$ control (Table 3 ). Biosolids and inorganic $\mathrm{N}$ treatments were applied by hand to the surface of the tall fescue stand with no incorporation. Each trial was continued through two growing seasons, to evaluate application year and residual year response to the biosolids applications.

Initial application rates were estimated to supply $250 \mathrm{~kg} \mathrm{ha}^{-1}$ plant available $\mathrm{N}$ based on $40 \%$ availability of $\mathrm{N}$ from the heat-dried biosolids [9]. Tall fescue showed less response to the Sumner biosolids than to Soundgro or Milorganite in a short-season preliminary experiment in 2006 (data not shown), so the Sumner biosolids were applied at higher rates in Trials A and B (Table 3). Rates for all biosolids in Trial B (2008) were adjusted downward based on the 2007 results. Urea $\mathrm{N}$ rates ranged from 90 to $270 \mathrm{~kg} \mathrm{ha}^{-1} \mathrm{~N}$ split over four applications in 2007, and were increased to 112 to $336 \mathrm{~kg} \mathrm{ha}^{-1} \mathrm{~N}$ split over five applications in 2008 and 2009. In the residual (second) year of both trials no biosolids applications were made, but all biosolids plots received $168 \mathrm{~kg} \mathrm{ha}^{-1} \mathrm{~N}$ as urea split over five applications (Table 3 ) to maintain grass vigor and obtain values for grass yield and $\mathrm{N}$ uptake near the center of the urea fertilizer response curves.

At the beginning of the experiment soil pH was 6.5. Ammonium acetate extractable $\mathrm{K}$ was $125 \mathrm{mg} \mathrm{kg}^{-1}$, Ca $5.5 \mathrm{cmol}_{\mathrm{c}} \mathrm{kg}^{-1}, \mathrm{Mg} 0.4 \mathrm{cmol}_{\mathrm{c}} \mathrm{kg}^{-1}$, and Bray-1 extractable 
TABLE 3: Biosolids and urea $\mathrm{N}$ fertilizer application amounts and timing for the ten treatments.

\begin{tabular}{|c|c|c|c|c|c|c|c|c|c|c|}
\hline \multirow[b]{2}{*}{ Year } & \multirow[b]{2}{*}{$\mathrm{N}$ source } & \multirow[b]{2}{*}{$\begin{array}{l}\text { Application } \\
\text { timing }\end{array}$} & \multirow[b]{2}{*}{$\begin{array}{l}\text { Application } \\
\text { dates }\end{array}$} & \multicolumn{7}{|c|}{ Annual application rate $\left(\mathrm{kg} \mathrm{ha}^{-1}\right.$ total $\left.\mathrm{N}\right)$} \\
\hline & & & & Soundgro & Milorg & Sumner & $\begin{array}{l}\text { Zero N } \\
\text { Control }\end{array}$ & $\begin{array}{l}\text { Low } \\
\text { Urea }\end{array}$ & $\begin{array}{l}\text { Med } \\
\text { Urea }\end{array}$ & $\begin{array}{l}\text { High } \\
\text { Urea }\end{array}$ \\
\hline \multicolumn{11}{|c|}{ Trial A } \\
\hline \multirow[b]{2}{*}{ Application Yr 2007} & Biosolids & Single $(1 \mathrm{X})$ & $16 \mathrm{Apr}$ & 630 & 592 & 907 & & & & \\
\hline & Biosolids & $\begin{array}{c}\text { Split } \\
(0.5 \times 2 \text { appl })\end{array}$ & 16 Apr, 14 Jun & 630 & 592 & 907 & & & & \\
\hline \multirow{4}{*}{ Residual Yr 2008} & Urea & $\begin{array}{c}\text { Split } \\
(0.25 \times 4 \text { appl })\end{array}$ & 17 Apr to $20 \mathrm{Jul}$ & & & & 0 & 90 & 180 & 270 \\
\hline & Biosolids & $\begin{array}{c}\text { Split } \\
(0.2 \times 5 \text { appl })\end{array}$ & 5 Mar to 8 Aug & $168 \mathrm{U}^{*}$ & $168 \mathrm{U}$ & $168 \mathrm{U}$ & & & & \\
\hline & Biosolids & $\begin{array}{c}\text { Split } \\
(0.2 \times 5 \mathrm{appl})\end{array}$ & 5 Mar to 8 Aug & $168 \mathrm{U}$ & $168 \mathrm{U}$ & $168 \mathrm{U}$ & & & & \\
\hline & Urea & $\begin{array}{c}\text { Split } \\
(0.2 \times 5 \text { appl })\end{array}$ & 5 Mar to 8 Aug & & & & 0 & 112 & 224 & 336 \\
\hline \multicolumn{11}{|c|}{ Trial B } \\
\hline \multirow[b]{2}{*}{ Application Yr 2008} & Biosolids & Single (1X) & $25 \mathrm{Apr}$ & 441 & 414 & 635 & & & & \\
\hline & Biosolids & $\begin{array}{c}\text { Split } \\
(0.5 \times 2 \mathrm{appl})\end{array}$ & 25 Apr, 3 Jul & 441 & 414 & 635 & & & & \\
\hline \multirow{4}{*}{ Residual Yr 2009} & Urea & $\begin{array}{c}\text { Split } \\
(0.2 \times 5 \text { appl })\end{array}$ & 25 Apr to 12 Sep & & & & 0 & 112 & 224 & 336 \\
\hline & Biosolids & $\begin{array}{c}\text { Split } \\
(0.2 \times 5 \text { appl })\end{array}$ & 4 Mar to $22 \mathrm{Jul}$ & $168 \mathrm{U}$ & $168 \mathrm{U}$ & $168 \mathrm{U}$ & & & & \\
\hline & Biosolids & $\begin{array}{c}\text { Split } \\
(0.2 \times 5 \text { appl })\end{array}$ & 4 Mar to $22 \mathrm{Jul}$ & $168 \mathrm{U}$ & $168 \mathrm{U}$ & $168 \mathrm{U}$ & & & & \\
\hline & Urea & $\begin{array}{c}\text { Split } \\
(0.2 \times 5 \mathrm{appl})\end{array}$ & 4 Mar to $22 \mathrm{Jul}$ & & & & 0 & 112 & 224 & 336 \\
\hline
\end{tabular}

$168 \mathrm{U}$ : In residual yr, $168 \mathrm{~kg} \mathrm{~N}$ ha $^{-1}$ of urea-N applied to all biosolids treatments, following same urea application schedule as urea the treatment plots.

TABLE 4: Monthly mean temperature, monthly precipitation, and irrigation applied during the growing season, March-October 2007-2009.

\begin{tabular}{|c|c|c|c|c|c|c|c|c|c|}
\hline & \multicolumn{3}{|c|}{ Mean temperature } & \multicolumn{3}{|c|}{ Precipitation } & \multicolumn{3}{|c|}{ Irrigation } \\
\hline & 2007 & 2008 & 2009 & 2007 & 2008 & 2009 & 2007 & 2008 & 2009 \\
\hline & \multicolumn{3}{|c|}{${ }^{\circ} \mathrm{C}$} & \multicolumn{3}{|c|}{$\mathrm{mm}$} & \multicolumn{3}{|c|}{$\mathrm{mm}$ and (number) } \\
\hline March & 8.6 & 5.8 & 5.6 & 138 & 86 & 121 & & & \\
\hline April & 9.6 & 7.7 & 9.1 & 32 & 46 & 87 & & & \\
\hline May & 12.5 & 13.2 & 12.8 & 28 & 22 & 77 & & & $38(2)$ \\
\hline June & 15.1 & 14.3 & 16.9 & 32 & 27 & 13 & $51(2)$ & $25(1)$ & $58(3)$ \\
\hline July & 18.8 & 17.2 & 19.6 & 29 & 23 & 0 & $51(2)$ & $71(3)$ & $89(4)$ \\
\hline August & 16.9 & 17.9 & 17.7 & 42 & 47 & 30 & $51(2)$ & $25(1)$ & $18(1)$ \\
\hline September & 14.2 & 14.4 & 15.3 & 54 & 9 & 70 & $23(1)$ & $25(1)$ & $18(1)$ \\
\hline October & 9.4 & 9.9 & 10.3 & 90 & 63 & 133 & & & \\
\hline
\end{tabular}

Numbers in parentheses in irrigation columns are number of irrigations in that month.

$\mathrm{P} 255 \mathrm{mg} \mathrm{kg}^{-1}$. Soil test $\mathrm{P}$ and $\mathrm{Ca}$ were adequate for grass forage production, while $\mathrm{K}$ was low, and $\mathrm{Mg}$ borderline [10]. To ensure adequate levels of all nutrients except $\mathrm{N}$, all plots received supplemental potassium $\left(176 \mathrm{~kg} \mathrm{ha}^{-1} \mathrm{~K}\right)$, sulfur $\left(45 \mathrm{~kg} \mathrm{ha}^{-1}\right)$, and magnesium $\left(22 \mathrm{~kg} \mathrm{ha}^{-1}\right)$ applied as $\mathrm{KCl}(0-0-62)$ and $\mathrm{K}_{2} \mathrm{SO}_{4} \cdot 2 \mathrm{MgSO}_{4}(0-0-22-22 \mathrm{~S}-11 \mathrm{Mg})$ each spring. The tall fescue was irrigated as needed to prevent moisture stress and maintain growth throughout the summer. Growing season rainfall, irrigation, and temper- atures during the experimental period are summarized in Table 4.

The tall fescue was harvested six times per year at the early boot stage using a small-plot forage harvester. A $1 \times$ $4.6 \mathrm{~m}$ swath was harvested from each plot at a height of $5 \mathrm{~cm}$. Because the initial biosolids applications were made after the first harvest of the application year, only five harvests are included in the application year experimental period for both trials. The second (residual) year includes all six harvests. 


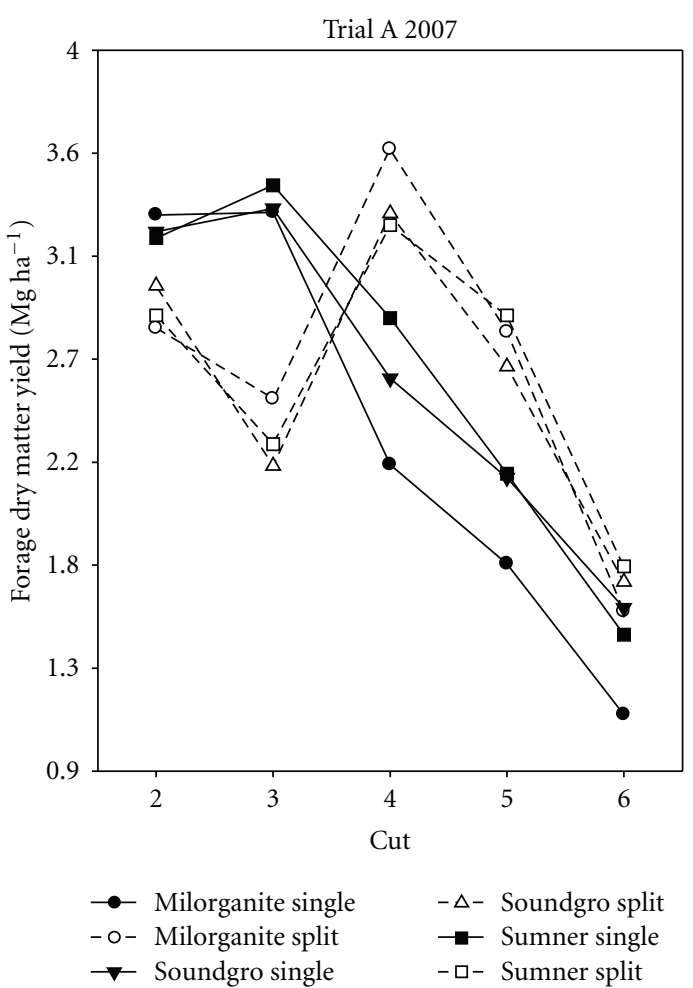

Figure 1: Comparison of single and split biosolids applications on tall fescue dry matter yield by harvest, Trial A application year.

The harvested forage from each plot was weighed wet, and a subsample (approximately $500 \mathrm{~g}$ ) was collected and oven dried at $55^{\circ} \mathrm{C}$ to determine dry matter. The dried subsample was then ground and analyzed for total $\mathrm{N}$.

Soils from selected plots (Soundgro and Sumner split application and $270 \mathrm{~kg} \mathrm{ha}^{-1}$ urea N) were sampled in October 2007 to determine residual soil nitrate- $\mathrm{N}$ at the onset of the rainy season. Samples were collected in $30 \mathrm{~cm}$ increments to a depth of $90 \mathrm{~cm}$ using a hydraulic probe with a $4 \mathrm{~cm}$ diameter. A minimum of three subsamples per depth and plot were collected and composited.

Total $\mathrm{N}$ was determined for biosolids and grass samples using a combustion analyzer (LECO Instruments, St. Joseph, MI). Biosolids ammonium $\mathrm{N}$ and soil nitrate $\mathrm{N}$ concentrations were measured after extraction with $2 \mathrm{M} \mathrm{KCl}$. Ammonium-N was determined using an automated salicylate-nitroprusside method and nitrate- $\mathrm{N}$ determined by an automated cadmium reduction method [11].

2.3. Data Analysis. Nitrogen uptake was calculated as the product of the yield and $\mathrm{N}$ concentration of the grass tissue. Statistics for yield and $\mathrm{N}$ uptake from the biosolids treatments were computed by ANOVA using a factorial design and the SAS General Linear Models procedure [12].

Apparent $\mathrm{N}$ recovery $\mathrm{N}$ from the biosolids was calculated in a two-step process. First, we used a linear regression of the $\mathrm{N}$ uptake at the different urea rates to calculate the fertilizer uptake efficiency of urea and background soil $\mathrm{N}$ availability:

$\mathrm{N}$ uptake $=$ urea efficiency $\times \mathrm{N}$ rate + background soil $\mathrm{N}$, where

(i) $\mathrm{N}$ rate is the amount of urea $\mathrm{N}$ applied at each rate $\left(\mathrm{kg} \mathrm{ha}^{-1}\right)$,

(ii) urea efficiency is the slope of the $\mathrm{N}$ uptake versus $\mathrm{N}$ rate regression (unitless) and represents the proportion of urea $\mathrm{N}$ taken up into the harvested fescue,

(iii) background soil $\mathrm{N}\left(\mathrm{kgha}^{-1}\right)$ is the intercept and represents fescue $\mathrm{N}$ uptake from the unamended soil,

Separate equations were calculated for each trial each year. Because clover became established in the zero-N plots in 2008 and 2009 and added fixed $\mathrm{N}$ to the system, we did not include $\mathrm{N}$ uptake from those plots in the urea regression equations after 2007, using only the fertilized plots for those years.

Apparent $\mathrm{N}$ recovery is an estimate of $\mathrm{N}$ uptake from the biosolids. It is the difference between $\mathrm{N}$ uptake from the biosolids treatment and $\mathrm{N}$ uptake in the zero- $\mathrm{N}$ control plots (assumed to be background soil N). When expressed as a percentage of total $\mathrm{N}$ applied, it estimates the fraction of the biosolids $\mathrm{N}$ captured in the harvested plant tissue. We calculated apparent $\mathrm{N}$ recovery for the application year of each trial by subtracting the intercept of the appropriate urea regression from the biosolids $\mathrm{N}$ uptake for the same trial. Dividing by the biosolids total $\mathrm{N}$ applied gives the apparent $\mathrm{N}$ recovery percentage:

$$
\begin{aligned}
& \text { Apparent } \mathrm{N} \text { recovery } \% \\
& =\left\{\frac{(\text { treatment } \mathrm{N} \text { uptake }- \text { background soil } \mathrm{N})}{\text { applied } \mathrm{N}}\right\} \times 100,
\end{aligned}
$$

where

(i) treatment $\mathrm{N}$ uptake $\left(\mathrm{kgha}^{-1}\right)$ is the amount of $\mathrm{N}$ captured in the harvested portion of the fescue for each treatment,

(ii) applied $\mathrm{N}\left(\mathrm{kg} \mathrm{ha}^{-1}\right)$ is the total amount of $\mathrm{N}$ applied in each biosolids treatment.

For the residual year of each trial, we modified the apparent $\mathrm{N}$ recovery equation to account for the $168 \mathrm{~kg} \mathrm{ha}^{-1}$ that was applied to all of the biosolids treatments that year:

Apparent $\mathrm{N}$ recovery \%

$$
=\left\{\frac{\left(\text { treatment } \mathrm{N} \text { uptake }-\mathrm{N}_{168}\right)}{\text { applied } \mathrm{N}}\right\} \times 100,
$$

where

(i) $\mathrm{N}_{168}$ represents $\mathrm{N}$ uptake from the $168 \mathrm{~kg} \mathrm{ha}^{-1}$ urea $\mathrm{N}$ treatment, derived from the appropriate urea $\mathrm{N}$ uptake regression for each trial.

Plant-available $\mathrm{N}$ (PAN) is an estimate of $\mathrm{N}$ release from the biosolids. PAN differs from apparent $\mathrm{N}$ recovery in that it includes available $\mathrm{N}$ that was not taken up into the harvested 
TABLE 5: Tall fescue dry matter yield and $\mathrm{N}$ uptake, Trials A and B, application year.

\begin{tabular}{|c|c|c|c|c|c|}
\hline \multirow{2}{*}{ Biosolids Source } & \multirow{2}{*}{ Application Timing } & \multicolumn{2}{|c|}{ Yield $\left(\mathrm{Mg} \mathrm{ha}^{-1}\right)$} & \multicolumn{2}{|c|}{$\mathrm{N}$ uptake $\left(\mathrm{kg} \mathrm{ha}^{-1}\right)$} \\
\hline & & Trial A 2007 & Trial B 2008 & Trial A 2007 & Trial B 2008 \\
\hline \multirow{2}{*}{ Soundgro } & Single & 13.0 & 9.8 & 371 & 259 \\
\hline & Split & 12.9 & 10.8 & 335 & 269 \\
\hline \multirow{2}{*}{ Sumner } & Single & 13.2 & 9.6 & 370 & 276 \\
\hline & Split & 13.1 & 10.6 & 355 & 281 \\
\hline \multirow{2}{*}{ Milorganite } & Single & 11.8 & 9.8 & 348 & 265 \\
\hline & Split & 13.3 & 10.9 & 345 & 269 \\
\hline \multirow{2}{*}{ Significance } & Source & NS & NS & NS & NS \\
\hline & Timing & NS & $* *$ & NS & NS \\
\hline
\end{tabular}

** Signficant at $P<.01$

NS: Not significant $(P>.05)$.

TABLE 6: Tall fescue dry matter yield and $\mathrm{N}$ uptake, Trials A and B, residual year.

\begin{tabular}{|c|c|c|c|c|c|}
\hline \multirow{2}{*}{ Biosolids Source } & \multirow{2}{*}{ Application Timing } & \multicolumn{2}{|c|}{ Yield $\left(\mathrm{Mg} \mathrm{ha}^{-1}\right)$} & \multicolumn{2}{|c|}{$\mathrm{N}$ uptake $\left(\mathrm{kg} \mathrm{ha}^{-1}\right)$} \\
\hline & & Trial A 2008 & Trial B 2009 & Trial A 2008 & Trial B 2009 \\
\hline \multirow{2}{*}{ Soundgro } & Single & 11.4 & 10.9 & 253 & 231 \\
\hline & Split & 10.9 & 11.1 & 236 & 246 \\
\hline \multirow{2}{*}{ Sumner } & Single & 11.7 & 11.3 & 262 & 248 \\
\hline & Split & 11.3 & 11.0 & 250 & 242 \\
\hline \multirow{2}{*}{ Milorganite } & Single & 10.1 & 10.1 & 220 & 214 \\
\hline & Split & 10.8 & 10.7 & 236 & 227 \\
\hline \multirow{2}{*}{ Significance } & Source & $*$ & NS & $*$ & $* *$ \\
\hline & Timing & NS & NS & NS & NS \\
\hline
\end{tabular}

${ }^{*}$ Significant at $P<.05$.

${ }^{*}$ * Significant at $P<.01$.

NS: Not significant.

TABle 7: Apparent N recovery and urea N equivalent from biosolids, application year. Single and split application data pooled.

\begin{tabular}{lcccccc}
\hline & \multicolumn{2}{c}{ Apparent N recovery $\left(\mathrm{kg} \mathrm{ha}^{-1}\right)$} & \multicolumn{2}{c}{ Apparent N recovery (\%) } & \multicolumn{2}{c}{ Urea N equivalent (\%) } \\
Treatment & Trial A 2007 & Trial B 2008 & Trial A 2007 & Trial B 2008 & Trial A 2007 & Trial B 2008 \\
\hline Soundgro & 240 & 159 & 38 & 36 & 61 & 72 \\
Sumner & 250 & 174 & 27 & 27 & 44 & 54 \\
Milorganite & 233 & 162 & 39 & 39 & 63 & 78 \\
\hline
\end{tabular}

part of the plant. This could include $\mathrm{N}$ in roots and crowns, or $\mathrm{N}$ lost to leaching or volatilization. PAN is used to compare $\mathrm{N}$ availability among different soil amendments. In this study we used urea $\mathrm{N}$ equivalent as a surrogate for PAN. Urea $\mathrm{N}$ equivalent (expressed as \% biosolids $\mathrm{N}$ ) is calculated by dividing the treatment apparent $\mathrm{N}$ recovery (\%) by the urea efficiency (slope) for the appropriate trial and year

Urea $\mathrm{N}$ equivalent \%

$$
=\frac{\text { (biosolids treatment apparent } \mathrm{N} \text { recovery } \%)}{\text { urea efficiency }} \text {. }
$$

\section{Results}

3.1. Tall Fescue Yield and N Uptake. Tall fescue yield and N uptake from the biosolids treatments in the application and residual years are shown in Tables 5 and 6 . Lower yields in the Trial B application year compared with Trial A reflect lower rates of biosolids application (Table 1). No treatment interactions between biosolids source and application timing were observed for either yield or $\mathrm{N}$ uptake. There was no significant effect of biosolids source on tall fescue yield or $\mathrm{N}$ uptake during the application year for either trial (Table 5). The biosolids were not applied at uniform rates, however, as the rate of the sumner product was about 50\% higher than Soundgro and Milorganite (Table 1). Biosolids source did affect yield in the residual year of Trial A and $\mathrm{N}$ uptake in the residual year of both trials with lower yield and $\mathrm{N}$ uptake from Milorganite (Table 6).

Splitting the biosolids application over two dates had only small effects on full-season tall fescue yield or $\mathrm{N}$ uptake. The only significant effect was increased yield with split application in the application year of Trial B. Split 
TABLE 8: Apparent N recovery and urea N equivalent from biosolids, residual year. Single and split application data pooled.

\begin{tabular}{|c|c|c|c|c|c|c|}
\hline \multirow[b]{2}{*}{ Treatment } & \multicolumn{2}{|c|}{ Apparent $\mathrm{N}$ recovery $\left(\mathrm{kg} \mathrm{ha}^{-1}\right)$} & \multicolumn{2}{|c|}{ Apparent $\mathrm{N}$ recovery $(\%)$} & \multicolumn{2}{|c|}{ Urea $\mathrm{N}$ equivalent $(\%)$} \\
\hline & Trial A 2008 & Trial B 2009 & Trial A 2008 & Trial B 2009 & Trial A 2008 & Trial B 2009 \\
\hline Soundgro & 35 & 28 & 6 & 6 & 9 & 10 \\
\hline Sumner & 46 & 34 & 5 & 5 & 8 & 8 \\
\hline Milorganite & 18 & 10 & 3 & 2 & 5 & 4 \\
\hline
\end{tabular}

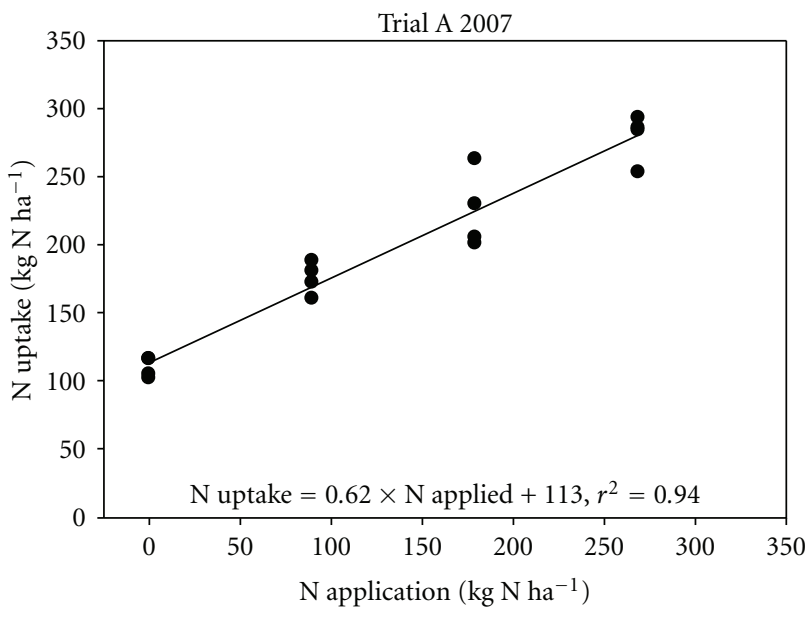

(a)

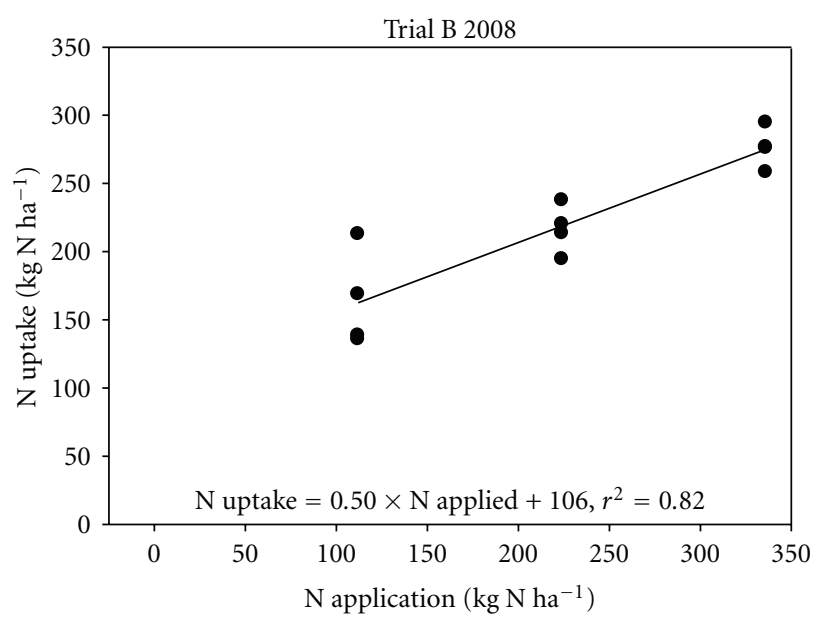

(c)

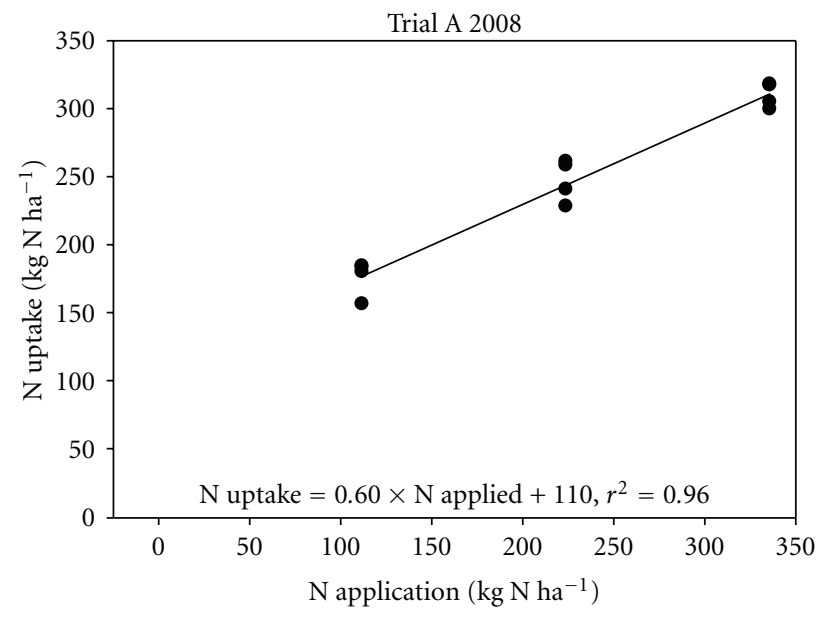

(b)

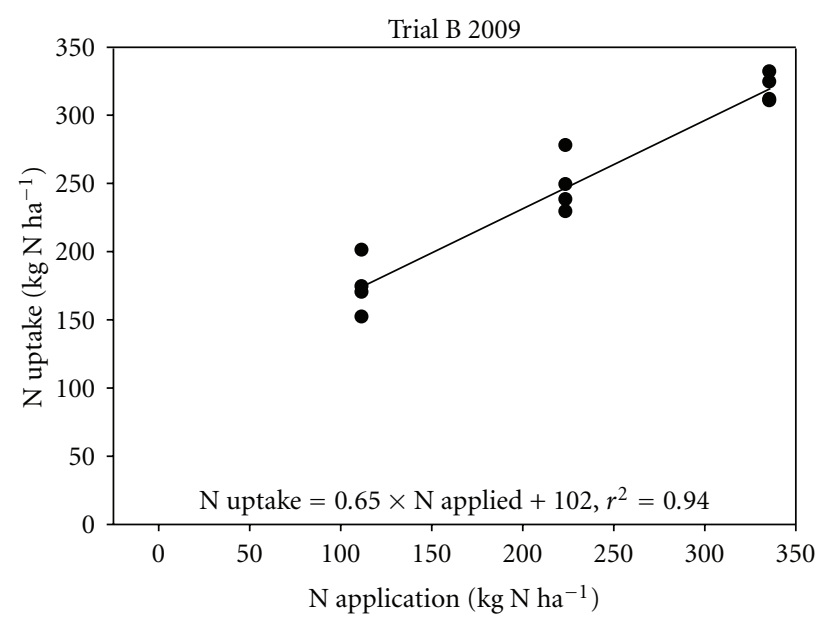

(d)

FIgURE 2: Harvested tall fescue $\mathrm{N}$ uptake versus inorganic N (urea) rate.

applications did result in more uniform yields across harvests in the application year (Trial A shown in Figure 1).

\subsection{Biosolids Apparent $N$ Recovery and Urea $N$ Equivalent.} Urea $\mathrm{N}$ uptake regressions were used in the calculation of biosolids apparent $\mathrm{N}$ recovery and urea $\mathrm{N}$ equivalent. A separate urea uptake regression was calculated for each trial each year (Figure 2). Intercepts (background soil N) were similar across the regressions, but the slope (urea uptake efficiency) was significantly lower in the Trial B application year than in the other regressions.

Apparent $\mathrm{N}$ recovery \% for the application year was similar across the two trials and was similar between Soundgro and Milorganite (Table 7). Apparent N recovery $\%$ was lower for the Sumner biosolids. Apparent N recovery $\%$ for Milorganite in this study (39\%) was greater than that reported in previous research (33\%) [5]. Application year urea $\mathrm{N}$ equivalent averaged $62 \%$ for Soundgro and 
Milorganite in Trial A and 75\% in Trial B (Table 7). The very high results in Trial B are likely an artifact of the low urea uptake efficiency observed in the fertilizer plots for the Trial $\mathrm{B}$ application year. Much less $\mathrm{N}$ was released in the residual year, with urea $\mathrm{N}$ equivalent estimated from 8 to $10 \%$ of $\mathrm{N}$ applied for the Soundgro and Sumner products, and 4 to 5\% for Milorganite (Table 8).

Postharvest soil nitrate $\mathrm{N}$ was low in the samples collected in 2007, and not different among the treatments sampled, averaging $4.0 \mathrm{mg} \mathrm{kg}^{-1}$ in the 0 to $30 \mathrm{~cm}$ depth, $2.8 \mathrm{mg} \mathrm{kg}^{-1}$ at 30 to $60 \mathrm{~cm}$, and $2.7 \mathrm{mg} \mathrm{kg}^{-1}$ and 60 to $90 \mathrm{~cm}$. This is consistent with results from treated and control plots in previous biosolids experiments done under similar conditions [7] and indicates little potential for leaching loss from the plots.

First-year available $\mathrm{N}$ from Milorganite and Soundgro was higher than previously reported for heat-dried biosolids under field conditions $[5,6]$. Similarly high first-year available $\mathrm{N}$ has been observed in laboratory incubations [1]. They reported 58 to $59 \%$ available $\mathrm{N}$ from lab incubations of three heat-dried biosolids. The Sumner biosolids had lower available $\mathrm{N}$, but still equal to or greater than observed for biosolids produced without heat drying. Second-year urea $\mathrm{N}$ equivalent in this study was similar to field PAN values for heat-dried biosolids reported previously $[5,6]$. The heat dried biosolids all tended to release $\mathrm{N}$ rapidly, with most of the yield response occurring in the first two harvests following an application (Figure 1).

These results show that first year available $\mathrm{N}$ (as urea $\mathrm{N}$ equivalent) for Milorganite and Soundgro exceed 60\%, which is greater than previously reported in the literature. Current guidelines for the Pacific Northwest of the USA recommend using mineralization estimates of 35 to $40 \%$ for heat-dried biosolids [9], but this research shows that at least some heat-dried materials fall above that range, meaning that these materials are effective at lower application rates. We expect these results can be extended to other temperate regions with adequate growing season rainfall or irrigation, based on the results of a previous multilocation field and modeling study of biosolids $\mathrm{N}$ availability [13]. Future research is needed to determine the relationship between specific heat drying processes and available $\mathrm{N}$ to improve estimates of $\mathrm{N}$ release from heat-dried products.

\section{Acknowledgments}

Funding for this project was provided by Pierce County Washington Public Works and Utilities, and the Agricultural Research Center at Washington State University through Hatch Project 0722.

\section{References}

[1] S. R. Smith and E. Durham, "Nitrogen release and fertiliser value of thermally-dried biosolids," Journal of the Chartered Institution of Water and Environmental Management, vol. 16, no. 2, pp. 121-126, 2002.

[2] H. Rigby, F. Perez-Viana, J. Cass, M. Rogers, and S. R. Smith, "The influence of soil and biosolids type, and microbial immobilisation on nitrogen availability in biosolids-amended agricultural soils-implications for fertiliser recommendations," Soil Use and Management, vol. 25, no. 4, pp. 395-408, 2009.

[3] K. Matsuoka, N. Moritsuka, T. Masunaga, K. Matsui, and T. Wakatsuki, "Effect of heating treatments on nitrogen mineralization from sewage sludge," Soil Science and Plant Nutrition, vol. 52, no. 4, pp. 519-527, 2006.

[4] N. Moritsuka, K. Matsuoka, S. Matsumoto, T. Masunaga, K. Matsui, and T. Wakatsuki, "Effects of the application of heated sewage sludge on soil nutrient supply to plants," Soil Science and Plant Nutrition, vol. 52, no. 4, pp. 528-539, 2006.

[5] C. G. Cogger, A. I. Bary, D. M. Sullivan, and E. A. Myhre, "Biosolids processing effects on first- and second-year available nitrogen," Soil Science Society of America Journal, vol. 68, no. 1, pp. 162-167, 2004.

[6] D. Gavalda, J. D. Scheiner, J. C. Revel et al., "Agronomic and environmental impacts of a single application of heat-dried sludge on an Alfisol," Science of the Total Environment, vol. 343, no. 1-3, pp. 97-109, 2005.

[7] C. G. Cogger, A. I. Bary, S. C. Fransen, and D. M. Sullivan, "Seven years of biosolids versus inorganic nitrogen applications to tall fescue," Journal of Environmental Quality, vol. 30, no. 6, pp. 2188-2194, 2001.

[8] Soil Survey Staff, Soil Taxonomy, Agricultural Handbook 436, USDA Natural Resources Conservation Service, 2nd edition, 1999.

[9] C. G. Cogger and D. M. Sullivan, Worksheet for calculating biosolids application in agriculture, PNW 511e. Washington State University Extension, 2007.

[10] J. Hart, G. Pirelli, L. Cannon, and S. Fransen, Fertilizer guide: Pastures in western Oregon and western Washington, FG-63. Oregon State University Extension, 2000.

[11] R. G. Gavlak, D. A. Horneck, and R. O. Miller, "Plant, soil and water reference methods for the western region," Western Regional Ext. Publ. 125. Univ. of Alaska, Fairbanks, 1994.

[12] SAS Institute, "SAS/STAT User's Guide: Statistics," Version 8. SAS Inst., Cary, NC, 1999.

[13] J. T. Gilmour, C. G. Cogger, L. W. Jacobs, G. K. Evanylo, and D. M. Sullivan, "Decomposition and plant-available nitrogen in biosolids: laboratory studies, field studies, and computer simulation," Journal of Environmental Quality, vol. 32, no. 4, pp. 1498-1507, 2003. 

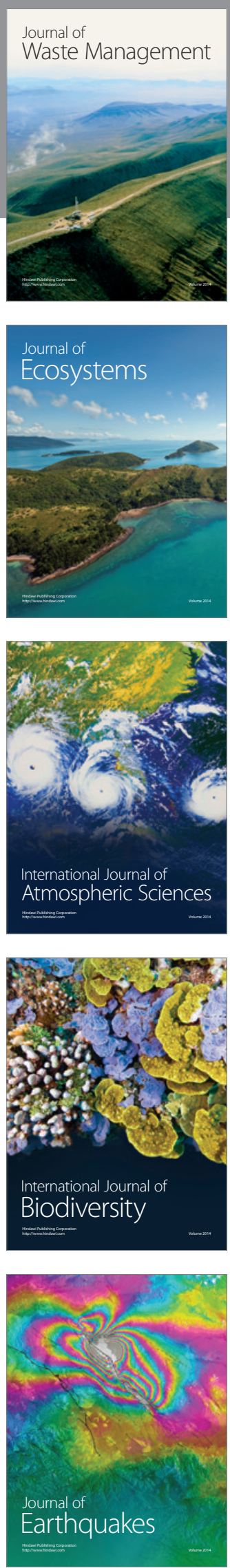
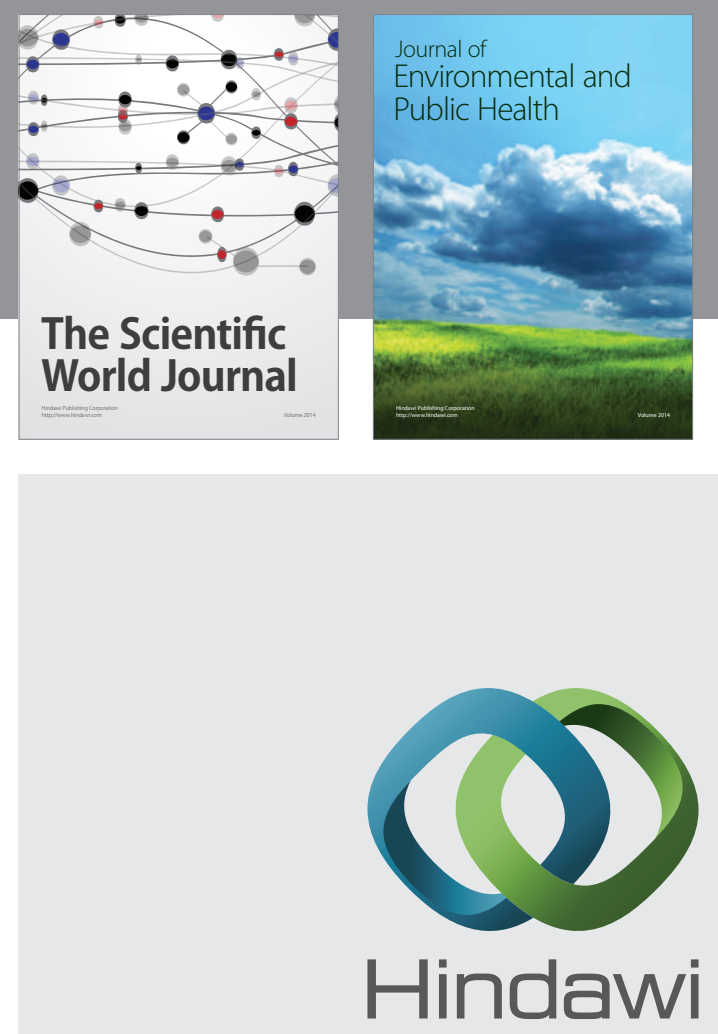

Submit your manuscripts at

http://www.hindawi.com
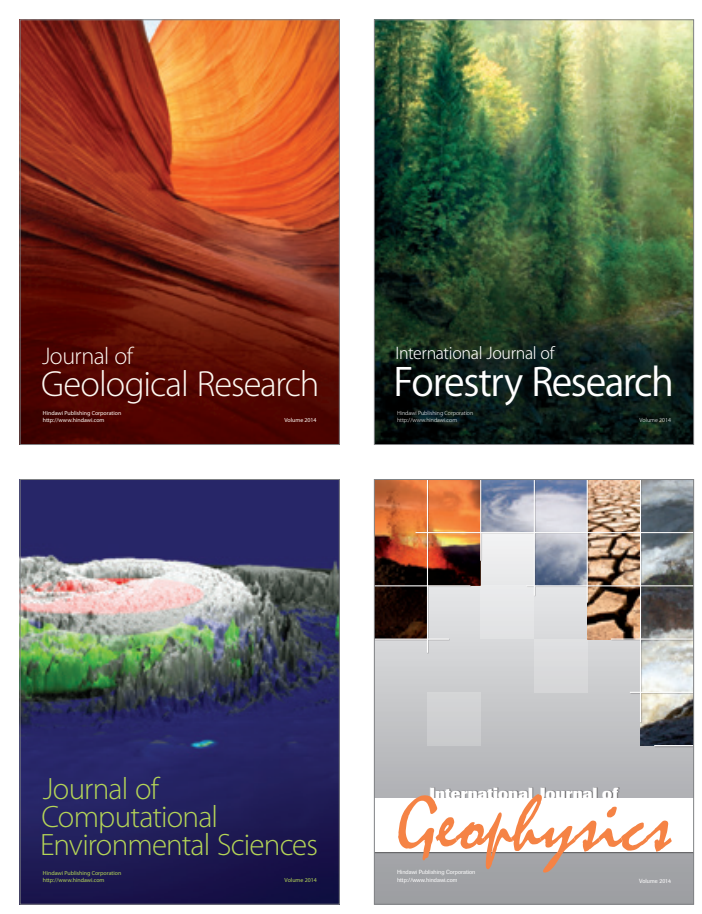
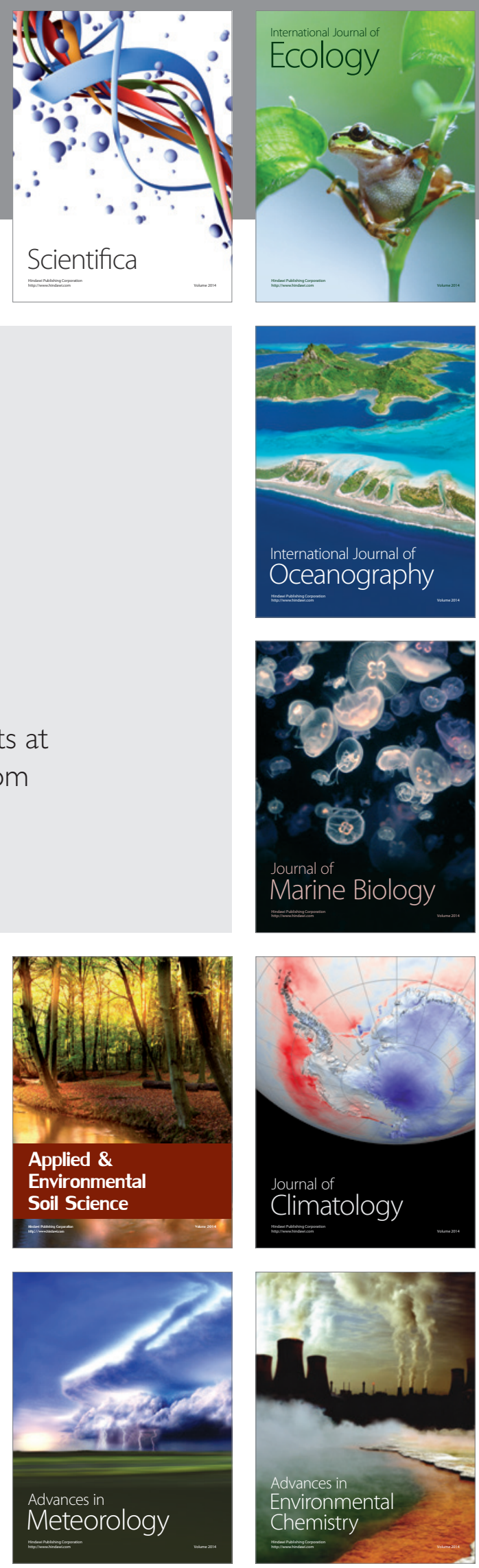